\title{
Facile Synthesis and Thermal Stability of Nanocrystalline Molybdenum Carbide
}

\author{
Youjian Chen ${ }^{1}$, Hong Zhang ${ }^{1}$, Jinfeng Zhang ${ }^{1}$, Jianhua Ma ${ }^{1,2^{*}}$, Hongnan Ye ${ }^{3}$, Gaojin Qian ${ }^{3}$, Yi Ye ${ }^{3}$, \\ Shuang Zhong ${ }^{3}$
}

${ }^{1}$ College of Chemistry and Materials Engineering, Wenzhou University, Wenzhou, China; ${ }^{2}$ Nanomaterials and Chemistry Key Laboratory, Advanced Materials Research Center of Wenzhou, Wenzhou University, Wenzhou, China; ${ }^{3}$ Oujiang college, Wenzhou University, Wenzhou, China.

Email: ${ }^{*}$ mjh820@ustc.edu

Received October $13^{\text {th }}, 2011$; revised February $9^{\text {th }}, 2011$; accepted July $12^{\text {th }}, 2011$.

\begin{abstract}
Nanocrystalline molybdenum carbide $\left(\mathrm{Mo}_{2} \mathrm{C}\right)$ was prepared via one simple route by the reaction of metallic magnesium powders with molybdenum trioxide and potassium acetate in an autoclave at the condition of $600{ }^{\circ} \mathrm{C}$ and $4 \mathrm{~h}$. X-ray powder diffraction $(X R D)$ pattern indicated that the product was hexagonal $\alpha-M o_{2} C$, and the cell constant was $a=$ $3.0091 A, c=4.7368$ A. Scanning electron microscopy (SEM) image showed that the sample consisted of particles with an average size of about $100 \mathrm{~nm}$ in diameter. The product was also studied by the thermogravimetric analysis (TGA). It had good thermal stability and oxidation resistance below $450^{\circ} \mathrm{C}$ in air.
\end{abstract}

Keywords: Molybdenum Carbide, Chemical Synthesis, X-Ray Diffraction, Thermogravimetric Analysis

\section{Introduction}

Molybdenum carbide, one of the most important compounds among transition metal carbides, due to its promising physical and chemical properties, such as a high melting temperature, high hardness, and high resistance to corrosion and oxidation, high abrasion resistance, good electrical conductivity. So it is widely used for cutting materials, abrasive, anti-wear and aerospace materials [1-4]. At the same time, $\mathrm{Mo}_{2} \mathrm{C}$ is used as a kind of catalyst in various reactions [5-10]; even it is usually superior to the noble metal catalysts in selectivity, stability and resistance to poison, so that $\mathrm{Mo}_{2} \mathrm{C}$ might be considered as a cheaper substitute for the noble metal catalysts. Because of the promising properties and extensive application of $\mathrm{Mo}_{2} \mathrm{C}$, it is meaningful to synthesize nanocrystalline $\mathrm{Mo}_{2} \mathrm{C}$, in a simple route at low temperature and with convenient manipulations.

Traditionally, mixing molybdenum powder with carbon black by annealing under argon flow or vacuum at a temperature between $1400^{\circ} \mathrm{C}$ and $1500^{\circ} \mathrm{C}$ can produce $\mathrm{Mo}_{2} \mathrm{C}$. Later, $\mathrm{Mo}_{2} \mathrm{C}$ is synthesised via the reaction of molybdenum oxide and high specific surface-active carbon at the lower reaction temperature [11]. Up to now, many approaches have been developed for the preparation of $\mathrm{Mo}_{2} \mathrm{C}$. Wang and co-workers [12] have shown that bulk face-centered-cubic (fcc)-based $\eta$ - $\mathrm{MoC}_{1-x}$ and hexagonal-close-packed (hcp)-based $\beta$ - $\mathrm{Mo}_{2} \mathrm{C}$ have been prepared using $\mathrm{C}_{3} \mathrm{H}_{8} / \mathrm{H}_{2}$ by temperature-programmed reaction method and a rapid heating method. Arceo et al [13] have reported hexagonal $\mathrm{Mo}_{2} \mathrm{C}$ have been synthesized by mechanical alloying with a mixture of carbon and molybdenum powder under argon atmosphere at 25 h, consequently. Norin et al. [14] have deposited singlephase molybdenum carbide films on sapphire by chemical vapour deposition using $\mathrm{C}_{60}$ as a carbon source. Yao [15] has used carbothermal reduction route to produce the $\beta-\mathrm{Mo}_{2} \mathrm{C}$ in the presence of a small amount of $\mathrm{H}_{2}$ at $950^{\circ} \mathrm{C}$. T. Miyao et al. [16] have prepared molybdenum carbide by nitridation of 12.5 wt $\% \mathrm{MoO}_{3} / \mathrm{Al}_{2} \mathrm{O}_{3}$ in a flow of $\mathrm{NH}_{3}$ at $700^{\circ} \mathrm{C}$, followed by carburization in a flow of $20 \% \mathrm{CH}_{4} / \mathrm{H}_{2}$ also at $700^{\circ} \mathrm{C}$ for $3 \mathrm{~h}$.

In this paper, we have developed a new convenient route to synthesize nanocrystalline hexagonal $\alpha-\mathrm{Mo}_{2} \mathrm{C}$ at low temperature by the reaction of metallic magnesium powders with $\mathrm{MoO}_{3}$ and $\mathrm{CH}_{3} \mathrm{COOK}$ in an autoclave at $600^{\circ} \mathrm{C}$. In this route, $\mathrm{MoO}_{3}$ as molybdenum source is more stable and safe in operation than other molybdenum source (e.g. $\mathrm{MoCl}_{5}$ ) and metallic magnesium powders as reductant are also more safe and convenient than other reductants (e.g. metallic sodium). Due to the whole syn- 
thesis route which is carried out in the sealed autoclave, so it can be obtained that all manipulations are rather safe and convenient, etc.

\section{Experimental}

In a typical experiment, analytical grade $\mathrm{MoO}_{3}$, analytical grade $\mathrm{CH}_{3} \mathrm{COOK}$ and analytical grade metallic magnesium powders were put into a mortar, followed by mixing these powders thoroughly. Then the mixture was put into a stainless steel autoclave. After sealing under argon atmosphere, the autoclave was heated at $600^{\circ} \mathrm{C}$ for $10 \mathrm{~h}$, followed by cooling to room temperature in the furnace. The obtained product from the autoclave was washed several times with absolute ethanol, dilute $\mathrm{HCl}$ aqueous solution, distilled water to remove the impurities. Finally the product was washed three times with absolute ethanol to remove water. The final product was vacuumdried at $60^{\circ} \mathrm{C}$ for $8 \mathrm{~h}$. Black powders were obtained.

The obtained sample was analyzed by powder X-ray diffraction (XRD) on a Bruker D8 Advance X-ray powder diffractometer using $\mathrm{Cu} \mathrm{K}-\alpha$ radiation (wavelength $\lambda$ $=1.54178 \AA$ ). The operating voltagewas $40 \mathrm{kV} .2$ theta angles were from $20^{\circ}$ to $90^{\circ}$. The morphology of the sample was observed from a JEOL JSM-6700F scanning electron microscope, the operating voltage was $10 \mathrm{kV}$. The thermogravimetric analysis was performed on a thermal analyzer (Model: Q600) below $900^{\circ} \mathrm{C}$ in air at a rate of $5^{\circ} \mathrm{C} \cdot \mathrm{min}^{-1}$ to study its thermal stability and oxidation behavior.

\section{Results and Discussion}

Figure 1 shows the XRD patterns of the as-prepared samples and $\mathrm{Mo}_{2} \mathrm{C}$ (JCPDS Card no. 35-0787). Pattern (a) shows the sample prepared under the condition of $600^{\circ} \mathrm{C}$ and $10 \mathrm{~h}$, there are eight obvious diffraction peaks in the pattern in Figure 1(a). And all these diffraction peaks ( $(1$ 0 0), (l $\left.\left.\begin{array}{lll}0 & 2\end{array}\right),\left(\begin{array}{lll}1 & 0 & 1\end{array}\right),\left(\begin{array}{lll}1 & 0 & 2\end{array}\right),\left(\begin{array}{lll}1 & 1 & 0\end{array}\right),\left(\begin{array}{lll}1 & 0 & 3\end{array}\right),\left(\begin{array}{lll}1 & 1 & 2\end{array}\right),\left(\begin{array}{lll}2 & 0 & 1\end{array}\right)\right)$ at different $d$-space can be indexed as hexagonal $\alpha-\mathrm{Mo}_{2} \mathrm{C}$. The refinement gives the cell constants $(a=3.0091 \AA, c$ $=4.7368 \AA$ ), which is consistent with the value reported in the literature $(a=3.0124 \AA, c=4.7352 \AA)$ (JCPDS card no. 35-0787). No evidences of crystal impurities such as molybdenum, molybdenum trioxide, other molybdenum carbides, can be found in this XRD pattern.

The morphology of the prepared $\mathrm{Mo}_{2} \mathrm{C}$ sample was investigated by field emission scanning electron microscopy. The SEM image of the as-prepared $\mathrm{Mo}_{2} \mathrm{C}$ sample is shown in Figure 2. In this figure, the samples show that it consists of particles with an average diameter of $100 \mathrm{~nm}$. These particles exhibit slightly agglomerated particle morphology due to the ultrafine size of the sample.

In order to investigate the thermal stability and the

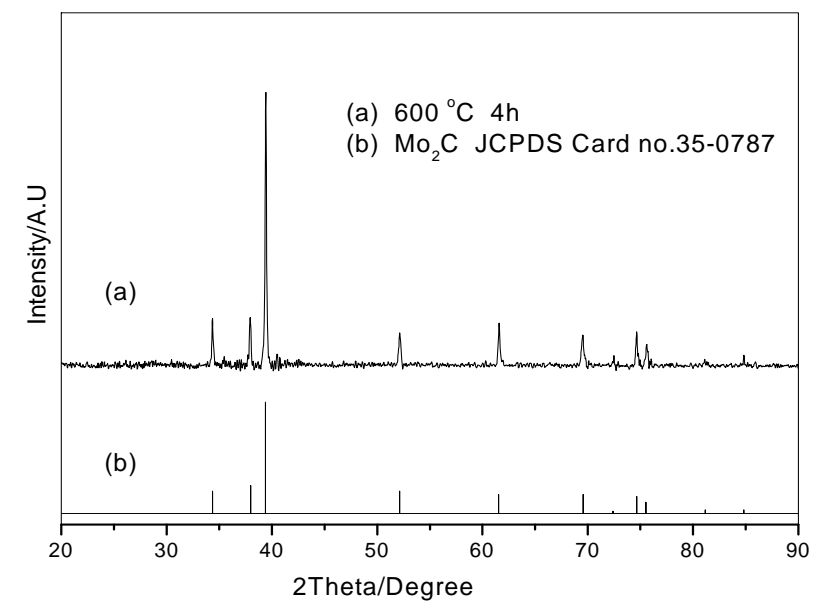

Figure 1. XRD patterns of the (a) as-prepared sample and (b) $\mathrm{Mo}_{2} \mathrm{C}$ (JCPDS Card no. 35-0787).

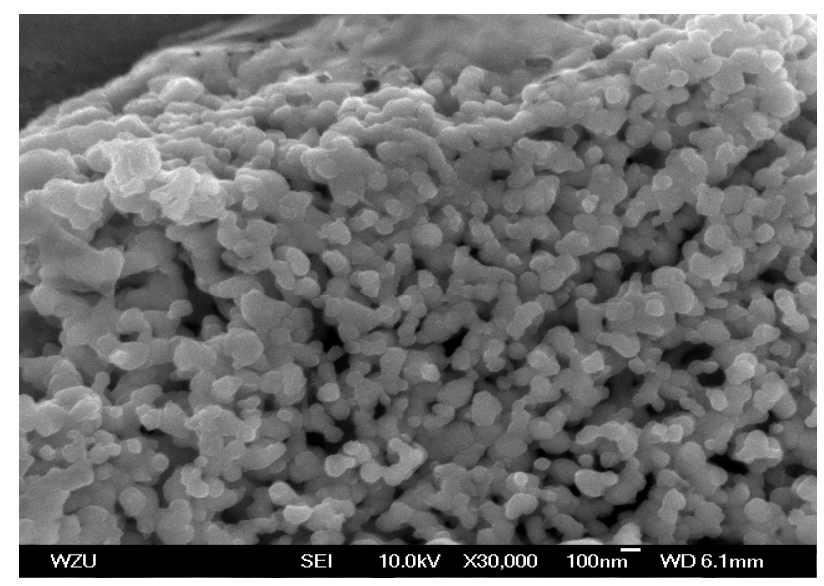

Figure 2. SEM image of the as-prepared sample prepared under the reaction condition of $600^{\circ} \mathrm{C}$ and $4 \mathrm{~h}$.

oxidation resistance of the as-prepared $\mathrm{Mo}_{2} \mathrm{C}$ powder by the thermogravimetric analysis (TGA), which was carried out at temperatures below $900^{\circ} \mathrm{C}$ under flowing air in Figure 3. In the figure, we can find that the weight of the product has not changed significantly below $350^{\circ} \mathrm{C}$. A slight weight loss indicates that the sample might adsorb a little water on the surface. However, an obvious weight loss step occurred in the temperature range of about $350^{\circ} \mathrm{C}$ to $450^{\circ} \mathrm{C}$, which may be attributed to oxidation of the graphite to form $\mathrm{CO}_{2}$ [17]. In this stage, the sample $\mathrm{Mo}_{2} \mathrm{C}$ is very stable. The $\mathrm{Mo}_{2} \mathrm{C}$ sample begines to oxidize at the temperature about $450^{\circ} \mathrm{C}$, indicating that the sample is oxidized to form molybdenum trioxide and carbon dioxide. The sample can be oxidized thoroughly at $550^{\circ} \mathrm{C}$. Therefore, the weight gain remains almost constant on the TGA curve when the temperature ranges of about $550^{\circ} \mathrm{C}$ to $720^{\circ} \mathrm{C}$. When the temperature exceeds $720^{\circ} \mathrm{C}$, the curve of the as-prepared $\mathrm{Mo}_{2} \mathrm{C}$ sample has suddenly declined, which is attributed to molybdenum 


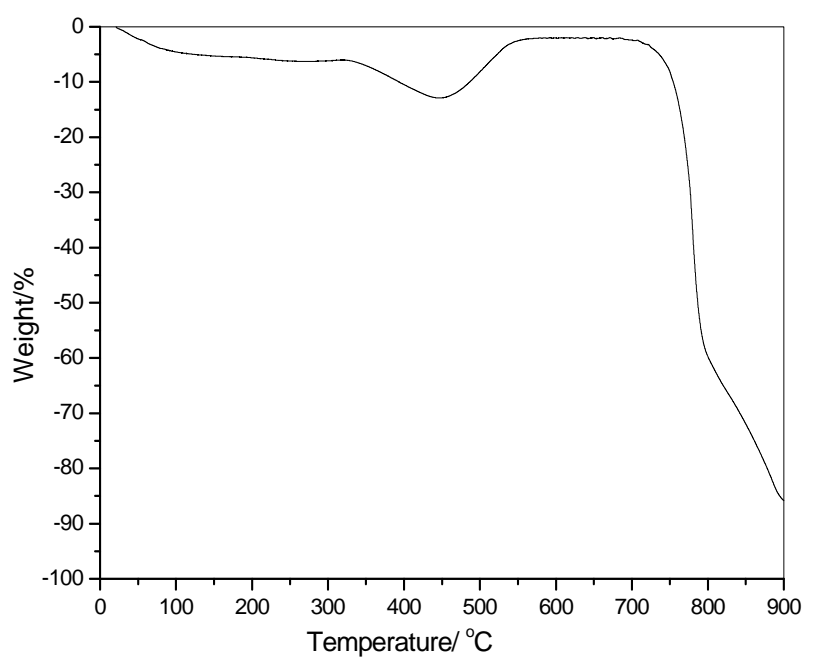

Figure 3. TGA curve of the as-prepared $\mathrm{Mo}_{2} \mathrm{C}$ sample in flowing air.

trioxide evaporated at this high temperature (about $740^{\circ} \mathrm{C}$ ). In a word, because of the ultrafine particles, the sample can be oxidized thoroughly at about $550^{\circ} \mathrm{C}$. But the sample has good thermal stability below $450^{\circ} \mathrm{C}$.

\section{Conclusions}

In summary, nanocrystalline molybdenum carbide $\left(\mathrm{Mo}_{2} \mathrm{C}\right)$ powder has been prepared via a simple thermal route by the reaction of metallic magnesium powders with molybdenum trioxide and potassium acetate in an autoclave at $600^{\circ} \mathrm{C}$ for $4 \mathrm{~h}$. The product crystalline structure is hexagonal. It consists of particles with an average size of $100 \mathrm{~nm}$. The product has good thermal stability and oxidation resistance below $450^{\circ} \mathrm{C}$.

\section{Acknowledgements}

This work was supported by Innovation and Promotion of science-technology project of Zhejiang Province and Department of Education of Zhejiang Province of China under Grant No. 20070546.

\section{REFERENCES}

[1] T. Hachisuka, "Role of Molybdenum Carbide in Promoting Densification During Sintering of TiC-TiN-Mo sub 2 C-Cr sub 3 C sub 2 Ceramic Composite," Journal of the Japan Society of Powder and Powder Metallurgy, Vol. 38, No. 2, February 1991, pp. 145-152. doi:10.2497/ijspm.38.145

[2] H. C. Kim, H. K. Park, I. K. Jeong, I. Y. Ko and I. J. Shon, "Sintering of Binderless WC- $\mathrm{Mo}_{2} \mathrm{C}$ Hard Materials by Rapid Sintering Process," Ceramics International, Vol. 34, No. 6, 2008, pp. 1419-1423. doi:10.1016/j.ceramint.2007.03.029

[3] Z. Guo, J. Xiong, M. Yang, J. Wang, L. Sun, Y. Wu, J.
Chen and S. Xiong, "Microstructure and Properties of $\mathrm{Ti}(\mathrm{C}, \mathrm{N})-\mathrm{Mo}_{2} \mathrm{C}-\mathrm{Fe}$ Cermets," International Journal of Refractory Metals \& Hard Materials, Vol. 27, No. 4, 2009, pp. 781-783.

[4] X. H. Wang, F. Han, X. M. Liu, S. Y. Qu and Z. D. Zou, "Effect of Molybdenum on the Microstructure and Wear Resistance of Fe-Based Hardfacing Coatings," Materials Science and Engineering A, Vol. 489, No. 1-2, 2009, pp. 193-200. doi:10.1016/j.msea.2007.12.020

[5] G. Z. Jin, J. H. Zhu, X. J. Fan, G. D. Sun and J. B. Gao, "Effect of Ni Promoter on Dibenzothiophene Hydrodesulfurization Performance of Molybdenum Carbide Catalyst," Chinese Journal of Catalysis, Vol. 27, No. 10, October 2006, pp. 899-903. doi:10.1016/S1872-2067(06)60046-6

[6] M. L. Xiang, D. B. Li , W. H. Li, B. Zhong and Y. H. Sun, "Performances of Mixed Alcohols Synthesis over Potassium Promoted Molybdenum Carbides," Fuel, Vol. 85, No. 17-18, 2006, pp. 2662-2665. doi:10.1016/j.fuel.2006.05.012

[7] E. C. Weigert, J. South, S. A. Rykov and J. G. Chen, "Multifunctional Composites Containing Molybdenum Carbides as Potential Electrocatalysts," Catalysis Today, Vol. 99, No. 3-4, 2005, pp. 285-290. doi:10.1016/j.cattod.2004.10.003

[8] M. Lewandowski, A. Szymanska-Kolasa, P. Da Costa and C. Sayag, "Catalytic Performances of Platinum Doped Molybdenum Carbide for Simultaneous Hydrodenitrogenation and Hydrodesulfurization," Catalysis Today, Vol. 119, No. 1-4, 2007, pp. 31-34.

doi:10.1016/j.cattod.2006.08.062

[9] J. M. Cheng and W. Huang, "Effect of Cobalt (Nickel) Content on the Catalytic Performance of Molybdenum Carbides in Dry-Methane Reforming," Fuel Processing Technology, Vol. 91, No. 2, February 2010, pp. 185-193. doi:10.1016/j.fuproc.2009.09.011

[10] M. Nagai and K. Matsuda, "Low-Temperature Water-Gas Shift Reaction over Cobalt-Molybdenum Carbide Catalyst," Journal of Catalysis, Vol. 238, No. 2, 2006, pp. 489-496. doi:10.1016/j.jcat.2006.01.003

[11] D. Mordenti, D. Brodzki and G. D. Mariadassou, "New Synthesis of $\mathrm{Mo}_{2} \mathrm{C} 14 \mathrm{~nm}$ in Average Size Supported on a High Specific Surface Area Carbon Material," Journal of Solid State Chemistry, Vol. 141, No. 1, 1998, pp. 114-120. doi:10.1006/jssc.1998.7925

[12] X. H. Wang, H. L. Hao, M. H. Zhang, W. Li and K. Y. Tao, "Synthesis and Characterization of Molybdenum Carbides Using Propane as Carbon Source," Journal of Solid State Chemistry, Vol. 179, No. 2, 2006, pp. 538-543. doi:10.1016/j.jssc.2005.11.009

[13] L. Díaz Barriga Arceo, E. Orozco, H. Mendoza-León, E. Palacios González, F. Leyte Guerrero and V. Garibay Febles, "Nanostructures Obtained from a Mechanically Alloyed and Heat Treated Molybdenum Carbide," Journal of Alloys and Compounds, Vol. 434-435, 2007, pp. 799802.

[14] L. Norin, U. Jansson and J.-O. Carlsson, "Chemical Va- 
pour Deposition of Molybdenum Carbides Using $\mathrm{C}_{60}$ as a Carbon Source," Thin Solid Films, Vol. 293, No. 1, 1997, pp. 133-137. doi:10.1016/S0040-6090(96)08987-0

[15] Z. W. Yao, "Exploration on Synthesis of Activated Carbon Supported Molybdenum Carbide, Nitride and Phosphide via Carbothermal Reduction Route," Journal of Alloys and Compounds, Vol. 475, No. 1, 2009, pp. L38-L41. doi:10.1016/j.jallcom.2008.07.130
[16] T. Miyao, I. S. Kura, M. Matsuoka, M. Nagai and S. T. Oyama, "Preparation and Characterization of AluminaSupported Molybdenum Carbide," Applied Catalysis A: General, Vol. 165, No. 1-2, 1997, pp. 419-428.

[17] D.-Y. Wang, C.-L. Chang and W.-Y. Ho, "Oxidation Behavior of Diamond-Like Carbon Films," Surface and Coatings Technology, Vol. 120-121, 1999, pp. 138-144. 